\title{
The mental health status of Mayan refugees after repatriation to Guatemala
}

\author{
Miriam Sabin, ${ }^{1}$ Keith Sabin, ${ }^{2}$ Hyoung Yong Kim, ${ }^{1}$ \\ Marianela Vergara, ${ }^{3}$ and Luis Varese ${ }^{3}$
}

Suggested citation

Sabin M, Sabin K, Kim HY, Vergara M, Varese L. The mental health status of Mayan refugees after repatriation to Guatemala. Rev Panam Salud Publica. 2006;19(3):163-71.

ABSTRACT Objective. Only one previous study had examined the epidemiology of mental health in Guatemalan refugees. The objective of this new study was to estimate the prevalence of mental illness and to assess factors associated with poor mental health among Guatemalan Mayan refugees who had been repatriated to Guatemala after spending 12-18 years in refugee camps in Mexico, and to compare the results for the repatriated Guatemalans with those for Guatemalan refugees who were continuing to live in Mexico.

Methods. In 2001 a cross-sectional survey of adults ( $\geq 16$ years) was conducted with random household sampling proportional to the population size in each of the five repatriation villages surveyed. Posttraumatic stress disorder (PTSD), anxiety, and depression were measured by the Harvard Trauma Questionnaire and the Hopkins Symptom Checklist-25.

Results. Together, the five repatriation villages had 565 households. Of the 565 households, 203 of them were approached to solicit study participation. A total of 179 households (one adult per household) agreed to participate, representing an overall participation rate of $88 \%$, and one-third of all the households in the five communities. The respondents had personally experienced a mean of 5.5 trauma events and had witnessed a mean of 7.3 other trauma events. Of the respondents, $8.9 \%$ met the symptom criteria for PTSD, $17.3 \%$ for anxiety, and $47.8 \%$ for depression. PTSD was associated with being seriously wounded and with having relatives or friends mutilated. Logistic regression analyses indicated that anxiety was associated with being sexually assaulted, being female, having friends or family mutilated, being seriously wounded, and having 6-12 children (vs. having 1-5 children). Depression was associated with having 6-12 children. Anxiety was significantly more prevalent among the refugees remaining in Mexico (54.4\%) than it was among the repatriated refugees $(17.3 \%)$. The difference in the prevalence rates was not significant for PTSD $(11.8 \%$ for refugees remaining in Mexico vs. $8.9 \%$ for those repatriated) or for depression (38.8\% for refugees remaining in Mexico vs. $47.8 \%$ for those repatriated).

Conclusions. Psychiatric morbidity was common among the repatriated Mayans. The repatriation of refugees involves moving an already vulnerable, often traumatized population back to a place of distressing memories and still-unsettled conditions. There is a need to consider and plan for adequate mental health services for repatriating refugees.

Key words Refugees; emigration and immigration; mental health; stress disorders, posttraumatic; Guatemala.

1 University of Georgia, School of Social Work, Athens, Georgia, United States of America. Send correspondence to: Miriam Sabin, Mailstop E-04, Centers for Disease Control and Prevention, 1600
Clifton Road, NE, Atlanta, Georgia 30333, United States of America; e-mail: msabin@cdc.gov; telephone: 404-639-8194; fax: 404-639-8114.
University of Georgia, College of Education, Athens, Georgia, United States of America.

3 United Nations High Commissioner for Refugees, Sub-office, Comitán, Chiapas, México. 
On 29 December 1996 a peace accord between the Guatemalan Government and a guerilla movement marked the end to a civil war that had lasted for 36 years and whose aftermath still affects Guatemala. During the conflict tens of thousands of Guatemalans experienced traumatic events that included disappearances, massacres, and rapes, and 441 villages were razed (1-4). (Disappearances are kidnappings in which the individual abducted often "disappears" or vanishes without the family knowing the whereabouts of the person or if the individual has been killed.) Ethnic Mayans were particularly impacted by the conflict, primarily in Huehuetenango and Quetzaltenango, two departments in western Guatemala.

Seeking to escape the violence in their country during the civil war, thousands of Mayan Guatemalans fled to Mexico. A cross-sectional study conducted in November and December of 2000 of Mayan Guatemalan refugees living in five United Nations High Commissioner for Refugees (UNHCR) refugee camps in Chiapas, Mexico's southernmost state, found that survey participants had high rates of anxiety $(54.4 \%)$, depression (38.8\%), and posttraumatic stress disorder (PTSD) $(11.8 \%)$ some 20 years after leaving Guatemala (5). (The respondents from the 2000 study in Chiapas had chosen to remain in Mexico and were in the process of becoming Mexican citizens, a process they completed in 2001.)

In 1993, UNHCR had brokered an agreement between the governments of Mexico and Guatemala that enabled refugees to repatriate to Guatemala in organized and protected caravans. The locations of repatriation varied. Some refugees went back to their original land, but in many cases the land was no longer available, or villages had been razed. Most refugees returned to their original departments, primarily Huehuetenango and Quetzaltenango (6-7). For 3 to 12 months after returning to Guatemala all the repatriated refugees received humanitarian assistance from the United Nations and numerous nongovernmental organizations, in the form of land, cash allowances, and food (8). However, the repatriated refugees' access to some UNHCR communitybased resources that had been available in Mexico, such as refugee camp health clinics and schools, ceased because they no longer had refugee status. The refugees repatriated to Guatemala have no routine access to psychiatric care, have limited access to health care and schools, and live under severe economic hardship, including insufficient food and income sources (9-10).

Due to the poor mental health outcomes found in 2000 among the Mayan Guatemalans still living in the UNHCR refugee camps in Mexico (5), the UNHCR Sub-office in Chiapas funded this survey to examine the mental health status of and the factors associated with poor mental health among Guatemalan Mayan refugees who had been repatriated to Guatemala after spending 12-18 years in refugee camps in Mexico.

\section{METHODS}

\section{Survey design}

We conducted a cross-sectional household survey in five remote highlands refugee repatriation villages in the department of Huehuetenango. Target sample sizes were proportional to the size of each village, and they were derived from UNHCR census data. Random starting points were selected, and alternating households were chosen for the recruitment of respondents, from every section of each of the villages. The villages were in designated UNHCR repatriation areas (the specific locations and community names are not given in order to protect the identity of the survey participants). The five village sites were selected using information from key informants at UNHCR and other nongovernmental aid organizations. To maintain and build on the validity of the study instruments used in the Chiapas survey (5) with a similar population of Mayan refugees in Guatemala, the five population settlements in Huehuetenango were chosen based on comparable demographic criteria (settlement size, having members of the two predominant Guatemalan Mayan subgroups (Kanjobal and Chuj) that were surveyed in the Chiapas (5) study), UNHCR information needs, and UNHCR prohibitions on their personnel traveling to certain unsafe regions of Guatemala.

Sample size was based on an estimated prevalence of PTSD of $11.8 \%$, derived from the study of the Mayan refugees living in Chiapas (5), and a precision level of $\pm 5 \%$ around the prevalence rate, with an allowance for a $10 \%$ household refusal rate in this field setting in Huehuetenango. A minimum of 176 persons was determined to meet sample size requirements. In order to begin a survey in a specific survey site, the field team used the precalculated sample size for each site (the five communities) and divided the sample size by the number of houses in that site to make the sample size proportional to the size of each community. Data collectors were instructed to follow a sampling scheme based on the number of houses in each community. The communities were mapped into sectors, and data collectors were sent to all sectors independently. If the target number of interviews per community was not initially met, the data collectors returned to their assigned sectors to interview persons in previously untargeted homes.

To randomize the selection of respondents, the data collectors asked which adult household resident (aged 16 and older) had last celebrated a birthday. The most recent birth date provided the person to be interviewed. All persons approached for interview knew their birth date. Only one adult per household was interviewed. Oral consent was obtained due to high rates of illiteracy. Respondents were asked to make an " $X^{\text {" on }}$ their form to indicate consent. Interviews were conducted individually in a private location inside the house or elsewhere on the property.

Data collection was conducted by a team of five data collectors, with on- 
site supervision by the project coordinator, who conducted nightly review meetings. The data collectors were Guatemalan refugees with a certificate in Spanish reading and writing, experience in fieldwork with refugees in Chiapas, and fluency in the two needed Mayan languages, Kanjobal and Chuj. A training session included rehearsals of questionnaire interviews in Spanish and in Kanjobal and Chuj. The training also covered the protection of human subjects, including implementing a mental health protocol to be followed if a respondent became upset during the interview. Approval was obtained from the University of Georgia Institutional Review Board.

\section{Screening tools}

The respondents answered demographic questions; the Harvard Trauma Questionnaire (HTQ) (11), a scale that measures the prevalence of symptom criteria for PTSD and trauma exposures validated for the sample population; and the Hopkins Symptom Checklist25 (HSCL-25), which assesses symptom scores for anxiety and depression (12). Both scales have been used extensively in refugee populations (13-16). The two scales, which had been used to measure the mental health status of the Mayan refugees in Chiapas (5), were validated at that time for content and language, and data analyses on the Cronbach's alpha levels indicated high reliability. Because no previously established cutoff points for PTSD existed for Guatemalan refugees and because psychometric testing is in process for the Chiapas version of the HTQ, an algorithm based on the PTSD case criteria of the Diagnostic and Statistical Manual of Mental Disorders, Fourth Edition (DSM-IV) was used to determine whether the respondents met the case definition for PTSD (17). In the HSCL-25, a score of 1.75 or higher was considered clinically significant (12).

The instruments were not translated into the two Mayan languages because they are not written languages. In order to compensate for variability in vocabulary during the interview process, the data collectors rehearsed previously agreed-upon vocabulary from the Chiapas survey to be used when a respondent did not speak Spanish with fluency or preferred that the interview be conducted in Kanjobal or Chuj. The survey among the Guatemalan refugees in Chiapas applied some of the same techniques used in a similar survey among another indigenous refugee group with no written language, Karenni refugees from Burma living in refugee camps in Thailand (18).

\section{Data analysis}

Data were entered and analyzed in SPSS for Windows version 12.0 software (19). Continuous variables were tested for normality using Levene's test. Differences in select demographics and mental health outcomes in the five study sites were measured for statistical significance using the $F$ test in the analysis of variance for all continuous variables. The chi-square test was used to assess associations among categorical variables. Following univariate analyses on all trauma exposures and selected demographic variables, multivariate logistic regression models using a backward elimination procedure were fitted to adjust for associations between and among factors and outcomes. Statistical significance in the multivariate logistic regression models was assessed at $P \leq 0.05$. Records with missing values were omitted for that analysis. Logistic regression analyses were conducted for all the participants together, not for the five study sites individually. We decided a priori that variables that remained in the logistic regression model that had wide confidence intervals would not be discarded from the final models for PTSD, anxiety, and depression. That was done in order to include the strength of association for select exposures, even if the number of persons who experienced these exposures was small. Factors other than gender that remained in a model that were not significant were excluded, and the model was retested.

\section{RESULTS}

The five Huehuetenango resettlement communities together had 565 households, with a total population of 3770 persons (adults and children). Of the 565 households, 203 of them were approached to solicit study participation in April and May of 2001. A total of 179 households (one adult per household) agreed to participate, representing an overall participation rate of $88 \%$ among the households approached, and one-third of all the households in the five communities. One 18-year-old male refused to respond to any of the trauma questions, and he was omitted from the analyses. Sample size targets for each site were met.

The demographic characteristics of the sample are displayed in Table 1. Of those surveyed, $64.2 \%$ were female. The respondents ranged in age from 17 to 81 , with a mean of 38.8 years $(95 \%$ confidence interval $(95 \% \mathrm{CI})=36.6-$ 41.0) and a median of 36 . Ninety-one percent of the respondents had resided in Chiapas prior to repatriation, and the other $9 \%$ came from other locations in southern Mexico. The mean number of years that respondents had lived in Mexico was 13.7 (95\% CI = 13.4-14.0). A little under half of the respondents had been repatriated to Guatemala in 1994. The mean number of persons living in a household (including the respondent) was 6.4 (95\% CI = 6.0-6.8). Forty-two percent of the respondents had 6-12 children living in the home with them at the time of the survey (that included both the respondent's own children and other children residing in the household). There was a mean number of 5.3 children per household $(95 \% \mathrm{CI}=$ 4.9-5.7).

\section{Trauma events}

Table 2 reports the proportion of the repatriated refugees who had experienced or observed particular trauma 
TABLE 1. Demographic characteristics of Guatemalan Mayan refugees who had been repatriated from Mexico to Guatemala $(n=179)$

\begin{tabular}{|c|c|c|}
\hline Characteristic & Number & Percent $^{\mathrm{a}}$ \\
\hline \multicolumn{3}{|l|}{ Gender } \\
\hline Female & 115 & 64.2 \\
\hline Male & 64 & 35.8 \\
\hline \multicolumn{3}{|l|}{ Marital status } \\
\hline Single & 7 & 4.0 \\
\hline Married & 160 & 90.9 \\
\hline Widowed & 8 & 4.5 \\
\hline Other & 1 & 0.6 \\
\hline Missing information & 3 & $N A^{b}$ \\
\hline \multicolumn{3}{|l|}{ Residence in Mexico } \\
\hline State of Chiapas & 155 & 90.6 \\
\hline Other states & 16 & 9.4 \\
\hline Missing information & 8 & NA \\
\hline \multicolumn{3}{|l|}{ Age (yr) } \\
\hline $17-35$ & 84 & 47.2 \\
\hline $36-81$ & 94 & 52.8 \\
\hline Missing information & 1 & NA \\
\hline \multicolumn{3}{|c|}{$\begin{array}{l}\text { Number of children living in the home } \\
\text { at the time of survey }\end{array}$} \\
\hline $1-5$ & 97 & 57.7 \\
\hline $6-12$ & 71 & 42.3 \\
\hline Missing information & 11 & NA \\
\hline \multicolumn{3}{|l|}{ Repatriation year } \\
\hline 1994 & 84 & 47.2 \\
\hline 1996-1999 & 86 & 48.3 \\
\hline Other years & 8 & 4.5 \\
\hline Missing information & 1 & NA \\
\hline \multicolumn{3}{|c|}{ Number of persons in household } \\
\hline $2-8$ & 142 & 80.2 \\
\hline $9-21$ & 35 & 19.8 \\
\hline Missing information & 2 & NA \\
\hline
\end{tabular}

events. The respondents reported directly experiencing a total of 836 traumatic events and witnessing 1137 others. The mean number of traumatic events directly experienced was 5.5 (95\% CI = 5.1-6.0); the mean number of traumatic events observed was 7.3 (95\% CI $=6.7-7.9)$. The trauma events could have occurred during the civil strife in Guatemala (before fleeing to Mexico), during the flight to Mexico, or in the refugee camps. Forty-eight percent reported being personally close to death, 33\% reported the murder of family or friends, and 28\% reported a relative or friend being massacred. Eight persons (4.5\%) had survived depression and therefore did not differ statistically. The 95\% CIs for anxiety did not overlap, indicating a statistically significant difference. Prevalence rates were not examined by study site in either the Mexico or Guatemala studies because the individual site sizes were too small to report with reasonable statistical confidence.

\section{Symptom criteria for PTSD}

Table 4 shows the results from univariate and multivariate analyses on demographic and PTSD traumatic exposure variables. Among the factors that were associated with a PTSD diagnosis were being seriously wounded, witnessing others being seriously wounded, experiencing forced separation from family, witnessing the murder of family or friends, witnessing others being abducted and disappearing, having friends or family mutilated, experiencing 11 to 15 trauma events, and experiencing sexual assault.

A multivariate logistic regression model was fitted with associated variables plus gender, because females and males experienced certain traumas differentially (e.g., sexual assault). In this model each variable was adjusted for the other variables retained in the final model. Four factors (being seriously wounded, having friends or family mutilated, gender, and sexual assault) were retained in the first model; however, sexual assault was not significant. The model was reanalyzed without sexual assault, and three factors were retained in the final model. Respondents who had been seriously wounded were seven and a half times as likely to have PTSD (Table 4). Respondents who had had friends or family mutilated during the conflict in Guatemala were eight and a half times as likely to have PTSD. Gender was retained in the final model, but was not significant. Gender was found to be a confounder requiring control in the model. Goodness of fit when including gender was assessed using the Hosmer and Lemeshow test. 
TABLE 2. Repatriated Guatemalan refugees reporting experience or observation of traumatic events $(n=179)^{a}$

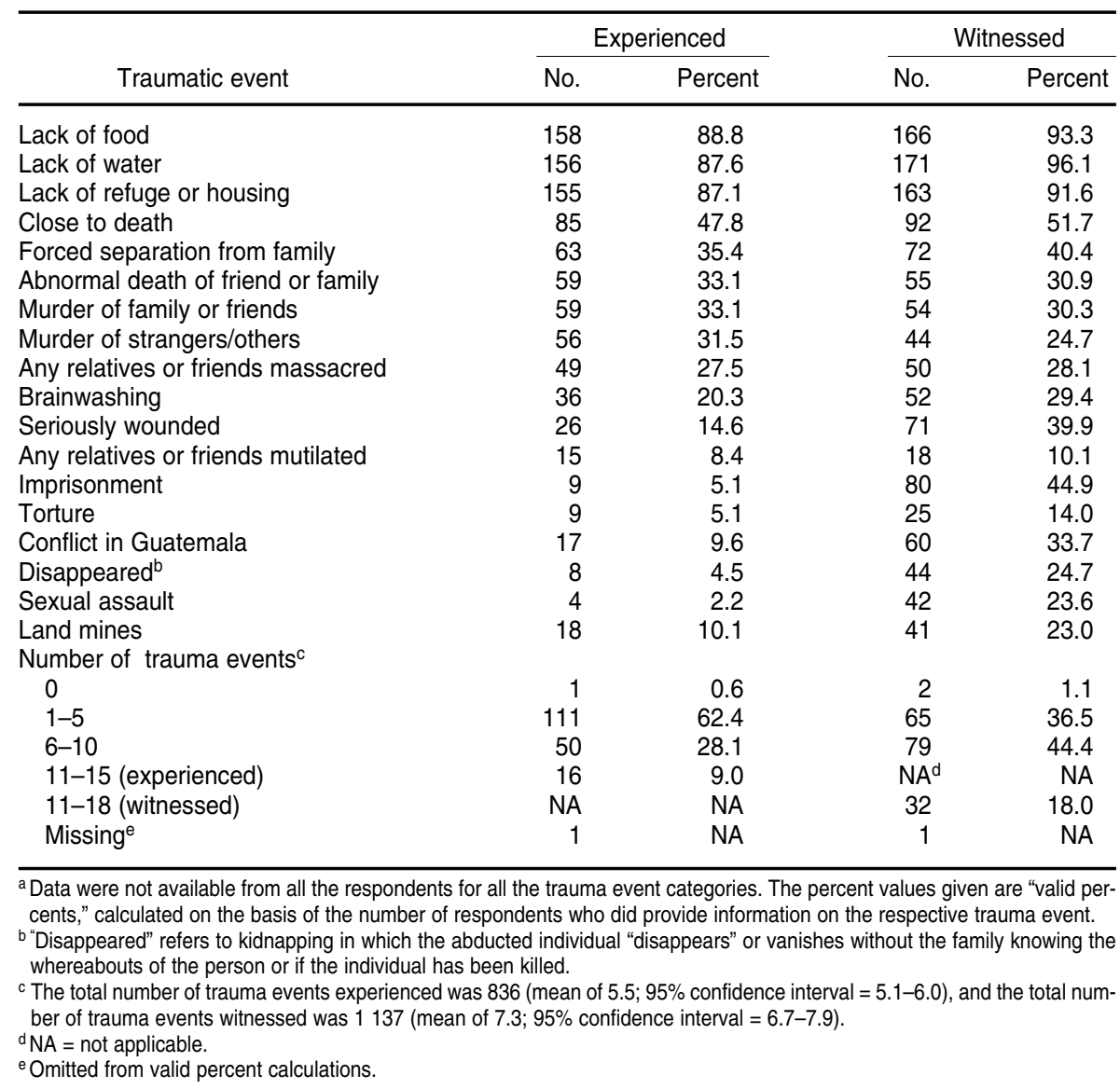

TABLE 3. Proportion of repatriated Guatemalan Mayan refugees reporting symptoms of posttraumatic stress disorder (PTSD), depression, or anxiety (with $95 \%$ confidence interval $(95 \% \mathrm{Cl}))$ compared to proportion for Guatemalan refugees remaining in Chiapas, Mexico

\begin{tabular}{|c|c|c|c|c|c|c|}
\hline \multirow[b]{2}{*}{ Sample } & \multicolumn{2}{|c|}{ PTSD } & \multicolumn{2}{|c|}{ Depression } & \multicolumn{2}{|c|}{ Anxiety } \\
\hline & $\%$ & $95 \% \mathrm{Cl}$ & $\%$ & $95 \% \mathrm{Cl}$ & $\%$ & $95 \% \mathrm{Cl}$ \\
\hline Refugees repatriated to Guatemala & 8.9 & $4.8-13.1$ & 47.8 & $40.4-55.1$ & 17.3 & $11.8-22.9$ \\
\hline Refugees remaining in Chiapas ${ }^{a}$ & 11.8 & $6.9-16.6$ & 38.8 & $31.2-46.3$ & 54.4 & $46.7-62.1$ \\
\hline
\end{tabular}

${ }^{a}$ Data from Sabin et al. (5).

\section{Anxiety symptoms}

Table 5 displays the univariate and multivariate analyses for anxiety. In the univariate analyses the respondent's number of children living in the home at the time of survey, experiencing 6-10 trauma events, experiencing
11-15 trauma events, being seriously wounded, experiencing sexual assault, and having friends or family who had been mutilated were associated with anxiety symptoms.

After adjusting for other factors (including gender) in the final logistic model, being sexually assaulted was the factor most strongly associated with anxiety symptoms (Table 5). Anxiety symptoms were also associated with having friends/family who were mutilated, being seriously wounded, being female, and having 6 to 12 children.

\section{Depression symptoms}

Table 6 displays the univariate and multivariate analyses for depression. Three exposures were associated with depression in univariate analyses: having 6 to 12 children, experiencing the death of a child, and being sexually assaulted. ("Death of a child" was asked about in the study, but it was not part of the "traumatic events" listing in Table 2. The death of the child could have occurred during the civil strife in Guatemala, while fleeing to Mexico, or while living as a refugee in Mexico. The death could have been due to various causes, e.g., miscarriage, malnutrition, or civil strife.) After adjusting for gender and death of a child, only respondents who had 6 to 12 children were more likely to have depression as compared with other respondents.

\section{Scale reliability}

Using Cronbach's alpha, the HTQ and the HSCL-25 were examined to determine the reliability of the scales in this study population. The HTQ's reliability level for the 24-item section on symptom criteria for PTSD was 0.91. Reliability testing of the 25-item HSCL25 yielded an alpha level of 0.94 .

\section{DISCUSSION}

According to the UNHCR (20), repatriation is an optimal outcome for refugees following the conclusion of large-scale conflicts. However, there have been only a few scientific studies (21-23) and UNHCR documents that have examined the mental health of repatriated refugees. We compared the mental health status of repatriated 
TABLE 4. Univariate and multivariate analyses for demographic and posttraumatic stress disorder (PTSD) traumatic exposure variables among repatriated Guatemalan refugees, $2001(n=179)^{\mathrm{a}}$

\begin{tabular}{|c|c|c|c|c|c|c|c|c|c|}
\hline \multirow[b]{2}{*}{ Respondent characteristic } & \multicolumn{2}{|c|}{ With PTSD } & \multicolumn{2}{|c|}{ Without PTSD } & \multirow{2}{*}{$\begin{array}{c}\text { Unadjusted } \\
P \text { value }\end{array}$} & \multicolumn{2}{|c|}{ Unadjusted odds ratio } & \multicolumn{2}{|c|}{ Adjusted odds ratio ${ }^{b, c}$} \\
\hline & No./Total with & $\%$ & No./Total w/o & $\%$ & & Ratio & $95 \% \mathrm{Cl}^{\mathrm{d}}$ & Ratio & $95 \% \mathrm{Cl}$ \\
\hline Sex & & & & & 0.35 & & & & \\
\hline Female & $12 / 16$ & 75 & $103 / 163$ & 63 & & 1.75 & $0.60-5.66$ & 3.90 & $0.95-16.08$ \\
\hline Age (yr) & & & & & 0.42 & & & & \\
\hline $17-35$ & $6 / 16$ & 38 & $78 / 162$ & 48 & & 1.00 & - & & - \\
\hline $36-81$ & $10 / 16$ & 63 & $84 / 162$ & 52 & & 1.55 & $0.54-4.46$ & & $\ldots{ }^{e}$ \\
\hline $1-5$ & $5 / 16$ & 31 & $92 / 152$ & 61 & & 1.00 & - & & - \\
\hline $6-12$ & $11 / 16$ & 69 & 60/152 & 39 & & 3.37 & $1.12-10.20$ & & $\ldots$ \\
\hline \multicolumn{10}{|l|}{ Traumatic event } \\
\hline Relatives or friends massacred & $6 / 16$ & 38 & $43 / 162$ & 27 & 0.35 & 1.66 & $0.06-4.84$ & & \\
\hline Seriously wounded & $7 / 16$ & 44 & 19/162 & 18 & 0.001 & 5.85 & $1.95-17.54$ & 7.53 & $2.20-25.80$ \\
\hline Witnessed others seriously wounded & $11 / 16$ & 69 & 60/162 & 37 & 0.01 & 3.74 & $1.24-11.28$ & & ... \\
\hline Sexual assault & $2 / 16$ & 13 & 2/162 & 1 & 0.004 & 11.42 & $1.49-87.43$ & & $\ldots$ \\
\hline Relatives/friends who were mutilated & $5 / 16$ & 31 & $10 / 162$ & 6 & 0.001 & 6.91 & $2.01-23.77$ & 8.56 & $2.12-34.49$ \\
\hline \multicolumn{10}{|l|}{ Number of trauma events experienced ${ }^{f}$} \\
\hline $1-5$ & $5 / 16$ & 31 & 106/161 & 66 & - & 1.00 & - & & - \\
\hline $6-10$ & $8 / 16$ & 50 & $42 / 161$ & 26 & 0.02 & 4.04 & $1.25-13.05$ & & $\ldots$ \\
\hline $11-15$ & $3 / 16$ & 19 & 13/161 & 8 & 0.04 & 4.89 & $1.05-22.89$ & & $\ldots$ \\
\hline
\end{tabular}

a Data were not available from all the respondents in all of the categories.

${ }^{\mathrm{b}}$ Adjusted for the other variables (respondent characteristics) retained in the final model.

${ }^{c}$ Missing values were not included in adjusted analyses.

d $95 \% \mathrm{Cl}=95 \%$ confidence interval.

e Ellipses $=$ not applicable because variable was not retained in the final model.

f One person with zero reported trauma events was omitted, along with one person who refused to respond to all the trauma questions.

TABLE 5. Univariate and multivariate analyses for anxiety symptoms among repatriated Guatemalan refugees, $2001(n=179)^{\mathrm{a}}$

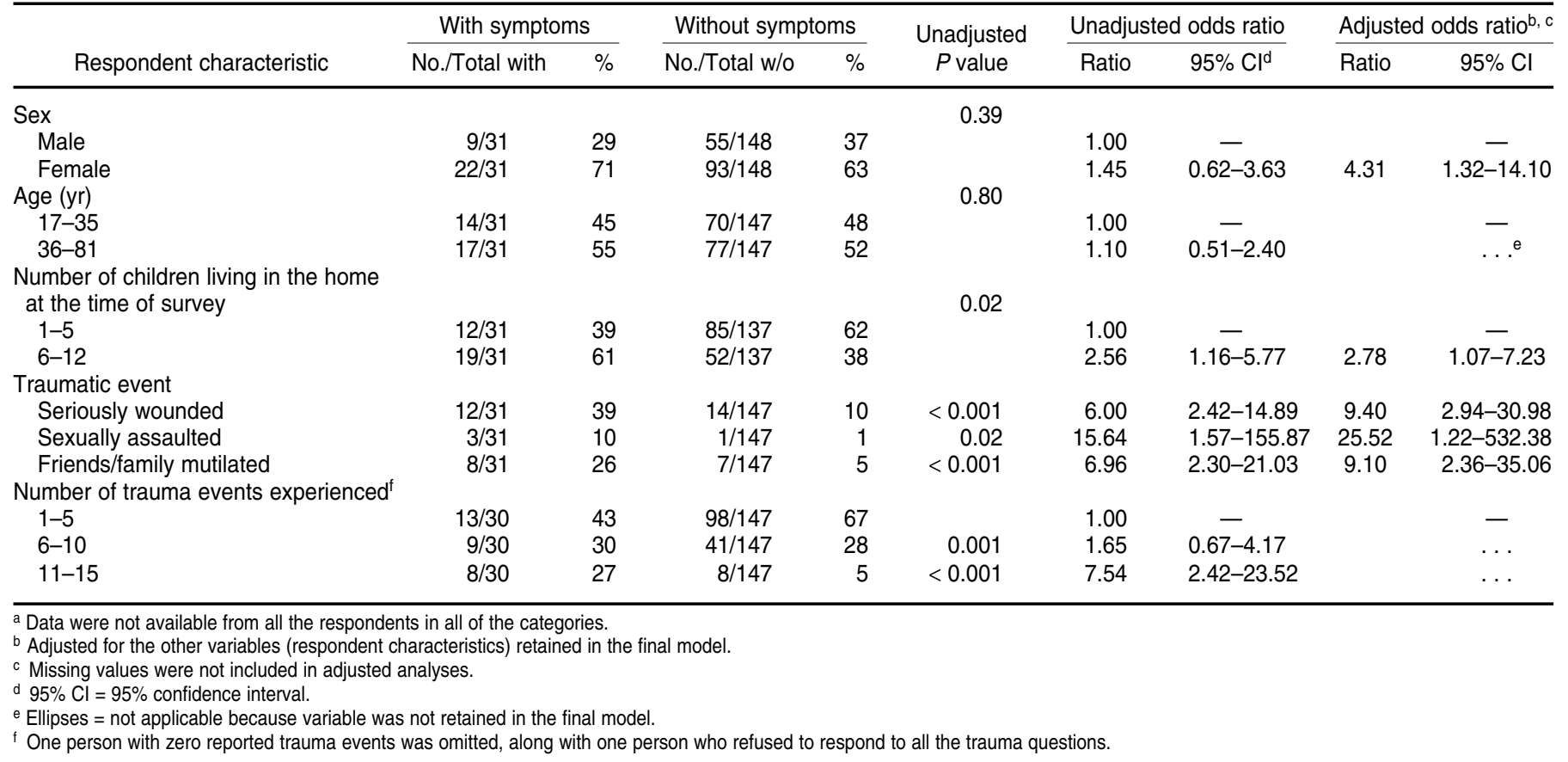


TABLE 6. Univariate and multivariate analyses for depression symptoms among repatriated Guatemalan refugees, $2001(n=179)^{\mathrm{a}}$

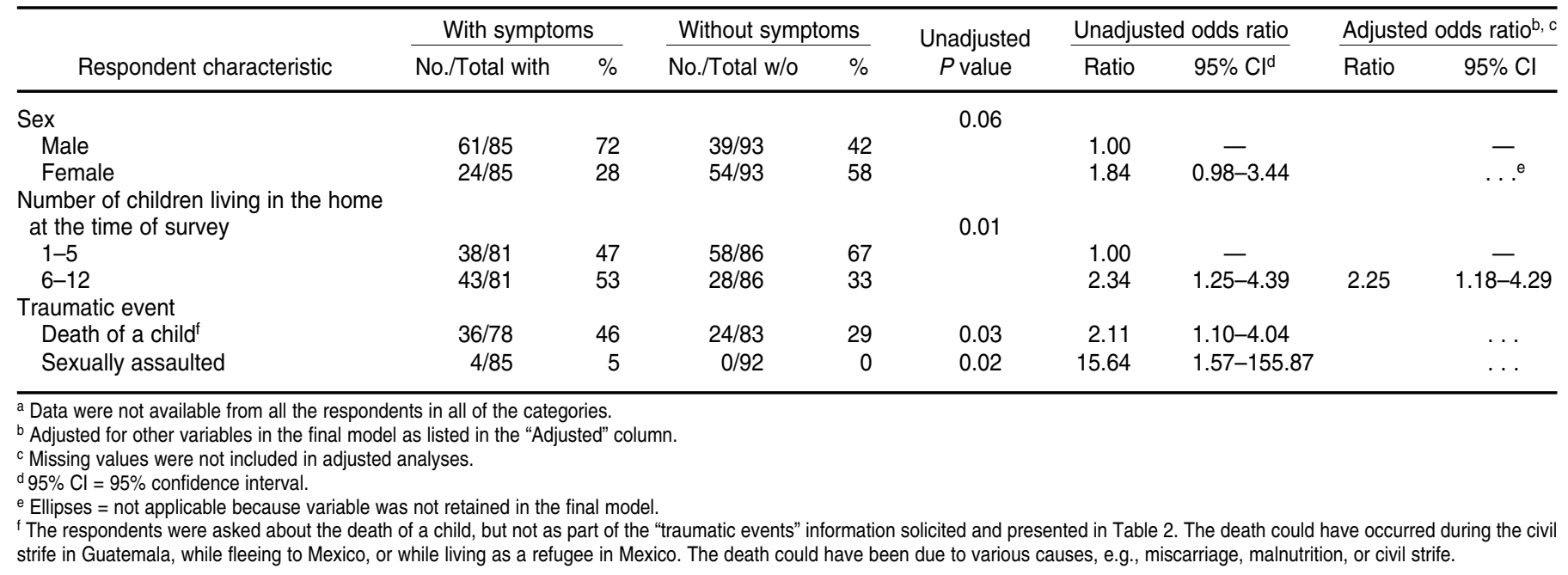

refugees in Guatemala with that of Mayan Guatemalan refugees remaining in Chiapas (5). The study questionnaires and the sociodemographic makeup were similar for the two groups, adding validity to the findings. Due to different sampling strategies, caution should be used in interpreting differences between the two study populations. The results from both studies lay a foundation for possible expectations of rates of psychiatric morbidity among Guatemalan refugees; that information may be useful for clinicians and researchers working on mental health issues with this population. There are many other factors that may contribute to poor mental health among repatriated refugees, such as limited access to land, housing, food, and monetary resources. However, an economic impact assessment was beyond the scope and resources of our study of the refugees repatriated to Guatemala.

The prevalence rate of anxiety that we found among the repatriated Mayan Guatemalans (17.3\%) was significantly lower than the level found in the Guatemalan refugees still living in Chiapas (54.4\%), but the $17.3 \%$ rate remains a concern. A UN-commissioned evaluation report (8) and previous qualitative fact-gathering (M. Sabin, unpublished data) indicated that the refugees who chose to remain in UNHCR camps in Chiapas feared being killed if they returned to Guatemala. Respondents in the Chiapas survey (5) had experienced and witnessed significantly more traumatic events than had the repatriated Guatemalans. The rates of PTSD were not statistically different, with the $8.9 \%$ rate among the repatriated refugees falling within the $11.8 \% \pm 5.0 \%$ prevalence rate range of the Chiapas study. The repatriated refugees' PTSD rate is also consistent with the level of $14.7 \%$ among Cambodian refugees living long-term in camps on the ThailandCambodia border (24). The $47.8 \%$ rate of depression among the repatriated Guatemalan Mayan refugees was 9.0\% higher than the $38.8 \%$ rate among the refugees remaining in Chiapas (5). Few studies have examined depression among repatriated refugees (22), and more research is needed.

Additional fact-gathering among the Guatemalan refugees in Chiapas might shed light on their higher prevalence of anxiety. The refugees surveyed in Chiapas said that they were choosing to not return to Guatemala because they were frightened that they would be victims of traumatic events again, such as violence by the Guatemalan Government. That is, the population who chose to remain in Chiapas may have done so because they had a higher level of anxiety or fear about Guatemala's past. Overall, the refugees who chose to return to Guatemala may have been more emotionally resilient to severe anxiety.

The repatriated refugee female respondents were at a statistically elevated risk for anxiety, and sexual assault was statistically associated with anxiety in the multivariate regression analyses. Findings from Guatemalan truth commissions of the United $\mathrm{Na}$ tions and the Human Rights Office of the Archdiocese of Guatemala indicated the regular use of rape to intimidate and torture Mayan women in the departments of Guatemala bordering Mexico $(1,4)$. Numerous studies of refugee women have documented the association between refugee status and sexual assault (25-27). Our data suggest that the repatriated refugees who had been victims of sexual assault may require mental health interventions. For the repatriated refugees, witnessing disappearances was significantly associated with PTSD in the univariate analyses but not so in the final model. In the Chiapas study this factor remained significant in the final model (5).

The Cronbach's alpha was used to measure internal reliability for the 
HTQ and HSCL-25, and both scales evidenced high reliability. These analyses are consistent with the Cronbach's alpha levels found in the Chiapas study (5). Although specific psychometric testing of the HTQ and the HSCL-25 should be conducted with additional samples of Guatemalan refugees, the results found so far indicate the consistency of both scales for use with this population.

\section{Limitations}

There are several important limitations to our study of the repatriated refugees. Sample size was calculated based on the estimated prevalence of PTSD in the population. The relatively small sizes of the five villages limit the statistical power to draw inferences about individual communities. However, the villages did not differ appreciably from one another in most measures, indicating that grouping them is valid.

It would have been preferable to have had an equal number of male and female data collectors so that men could interview men and women could interview women. The uneven number may have resulted in underreporting of gender-sensitive data. Men and women who were working outside the home or who were not at home at the time of data collection did not have an equal opportunity to be interviewed.

Wide confidence intervals were common in the logistic regression models, in particular for sexual assault and anxiety, thus weakening the assurance that the adjusted odds ratios for certain exposures were precise estimates. Despite low power to detect statistical differences in certain instances, several differences were detected, thus suggesting the validity of the results. The HTQ and HSCL-25 provide an estimate or proxy of PTSD, anxiety, and depression, and the two scales cannot provide formal, clinical diagnoses.

\section{Conclusions}

Poor mental health appears to be endemic among the repatriated Guatemalan Mayan refugees. The repatriation of refugees involves moving an already vulnerable, possibly trauma- tized population back to a place of distressing memories and still-unsettled conditions. Therefore, in the repatriation and integration process there is a need to consider and plan for adequate mental health services for refugees.

Acknowledgments. This study was made possible by the participating repatriation communities in Guatemala and by the Guatemalan refugee data collectors, who provided invaluable technical assistance for this study. We also wish to gratefully acknowledge intellectual and editorial support from Barbara Lopes Cardozo (Centers for Disease Control and Prevention (CDC), Division of Emergency and Environmental Health Sciences, International Emergency and Refugee Health Branch), Ian Williams (CDC, Division of Viral Hepatitis, Epidemiology Branch), and Elois Ann Berlin (University of Georgia (UGA) Department of Anthropology). Editorial support was provided by Angelica La Luz and Bryce Smith (UGA School of Social Work). This study was funded by the United Nations High Commissioner for Refugees, Sub-office, Chiapas, Mexico.

\section{REFERENCES}

1. Ball $P$, Kobrak $P$, Spirer HF. State violence in Guatemala, 1960-1996: a quantitative reflection. Washington, D.C.: American Association for the Advancement of Science; 1999.

2. Lykes MB. Terror, silencing and children: international, multidisciplinary collaboration with Guatemalan Maya communities. Soc Sci Med. 1994;38:543-52.

3. Miller K. The effects of state terrorism and exile on indigenous Guatemalan refugee children: a mental health assessment and an analysis of children's narratives. Child Dev. 1996;67:89-106.

4. Human Rights Office of the Archdiocese of Guatemala. Guatemala. Never again! REHMI: Recovery of Historical Memory Project. The official report of the Human Rights Office, Archdiocese of Guatemala. Maryknoll: Orbis Books; 1999.

5. Sabin M, Lopes Cardozo B, Nackerud L, Kaiser R, Varese L. Factors associated with poor mental health among Guatemalan refugees living in Mexico 20 years after civil conflict. JAMA. 2003;290(5):635-42.

6. México, Secretaría de Gobernación, Comisión Mexicana de Ayuda a Refugiados. Memoria: presencia de los refugiados guatemaltecos en México. México, D.F.: Fondo de Cultura Económica; 2000.

7. Goldberg D. From refugee to citizen: a Guatemalan in Mexico. Available from: http:// www.unhcr.ch/cgi-bin/texis/vtx/h... qS2npwBGowBodDaBdaH1wBnMwcdw / opendoc.htm [Internet site]. Accessed 19 March 2002.

8. Worby P. Lessons learned from UNHCR's involvement in the Guatemala refugee repatriation and reintegration programme (19871999). Available from: http://www.unhcr. ch/cgi-bin/texis/vtx/home/+pwwBmepx 269wwwwwwwwwwwwhFqo20I0E2gl+ FqoGn5nwGqrAFqo20I0E2glcFqcpw1cwaid GxODMXwwwwwww/opendoc.pdf [Internet site]. Accessed 14 October 2003.

9. Médecins Sans Frontières. Guatemala: poverty and geography limit access to care. Available from: http://www.msf.org/content/ page.cfm?articleid $=6589$ C506-DC2C-11D4B2010060084A [Internet site]. Accessed 16 January 2003.

10. World Bank. Guatemala: country brief, 1999. Available from: http://wbln0018.worldbank. org / External / ...49ae1fea1d852567d 90070 cbd9?Opendocument [Internet site]. Accessed 2 March 2003.

11. Mollica RF, Caspi-Yavin Y, Bollini P, Truong T, Tor S, Lavelle J. The Harvard Trauma Questionnaire: validating a cross-cultural instrument for measuring torture, trauma, and posttraumatic stress disorder. J Nerv Ment Dis. 1992;180:111-6.

12. Mollica RF, Wyshak G, de Marneffe D, Khuon F, Lavelle J. Indochinese versions of the Hopkins Symptom Checklist-25: a screening instrument for the psychiatric care of refugees. Am J Psychiatry. 1987;144:497-500.

13. Crescenzi A, Ketzer E, Van Ommeren M, Phuntsok K, Komproe I, de Jong JT. Effect of political imprisonment and trauma history on recent Tibetan refugees in India. J Trauma Stress. 2002;15:369-75.

14. Lie BA. A 3-year follow-up study of psychosocial functioning and general symptoms in settled refugees. Acta Psychiatr Scand. 2002;106:415-25.

15. Mollica RF, Poole C, Son L, Murray C, Tor S. Effects of war trauma on Cambodian refugee adolescents' functional health and mental 
health status. J Am Acad Child Adolesc Psychiatry. 1997;36:1098-1106.

16. Mollica RF, McInnes K, Sarajlic N, Lavelle J, Sarajlic I, Massagli M. Disability associated with psychiatric comorbidity and health status in Bosnian refugees living in Croatia. JAMA. 1999;282:433-9.

17. American Psychiatric Association. Diagnostic and statistical manual of mental disorders. 4th ed. Washington, D.C.: APA; 1994.

18. Lopes Cardozo B, Talley L, Burton A, Crawford C. Karenni refugees living in ThaiBurmese border camps: mental health outcomes, cross-cultural factors and landmine injuries. Soc Sci Med. 2004;58(12):2637-44.

19. SPSS Inc. Statistical Product and Service Solutions (SPSS) for Windows [computer program]. Version 10.0. Chicago: SPSS; 1999.
20. United Nations High Commissioner for Refugees. Voluntary repatriation: international protection. Geneva: UNHCR; 1996.

21. Lopes Cardozo B, Vergara A, Agani F, Gotway C. Mental health, social functioning, and attitudes of Kosovar Albanians following the war in Kosovo. JAMA. 2000;284:569-77.

22. Savin D, Sack WH, Clarke GN, Meas N, Richart I. The Khmer Adolescent Project: III. A study of trauma from Thailand's Site II refugee camp. J Am Acad Child Adolesc Psychiatry. 1996;35:384-91.

23. Sundquist J, Johansson SE. The influence of exile and repatriation on mental and physical health. A population-based study. Soc Psychiatry Psychiatr Epidemiol. 1996;31:21-2.

24. Mollica RF, Donelan K, Tor S, Lavelle J, Elias C, Frankel M, et al. The effect of trauma and confinement on functional health and mental health status of Cambodians living in ThaiCambodian border camps. JAMA. 1993;270: 581-6.

25. Iacopino V, Frank MW, Bauer HM, Keller AS, Fink SL, Ford D, et al. A population-based assessment of human rights abuses committed against ethnic Albanian refugees from Kosovo. Am J Public Health. 2001;91:2013-8.

26. LaMont-Gregory E, Matenge MN. Violence and internally displaced women and adolescent girls [letter to the editor]. Lancet. 2002; 359:1782.

27. Ward J, Vann B. Gender-based violence in refugee settings. Lancet. 2002;360:13-4.

Manuscript received 21 March 2005. Revised manuscript accepted for publication 1 September 2005.

RESUMEN Objetivo. Existe un solo estudio en el que se hayan examinado las tendencias epidemiológicas observadas en el ámbito de la salud mental en refugiados guatemaltecos. El objetivo de este nuevo estudio radica en calcular la prevalencia de enfermedades mentales y evaluar los factores asociados con el menoscabo de la salud mental en refugiados guatemaltecos de ascendencia maya que fueron repatriados a Guatemala después de pasar de 12 a 18 años en campamentos para refugiados en México, así como comparar los resultados observados en los guatemaltecos repatriados con los observados en refugiados guatemaltecos que siguieron viviendo en México.

Métodos. En 2001 se llevó a cabo una encuesta transversal de adultos ( $\geq 16$ años de edad) con muestras aleatorias de un tamaño que guardaba proporción con el de la población de cada una de las cinco aldeas de repatriados que se estudiaron. Se determinó la prevalencia del síndrome de estrés postraumático (SEP), de estados de ansiedad y de depresión mediante el Cuestionario de trauma de Harvard (Harvard Trauma Questionnaire) y la Lista 25 de verificación de síntomas de Hopkins (Hopkins Symptom Checklist-25).

Resultados. En las cinco aldeas de repatriados había en conjunto 565 hogares, de los cuales 203 fueron abordados para solicitar su participación en el estudio. Aceptó participar un total de 179 hogares (un adulto en cada hogar), equivalente a $88 \%$ de la muestra y a una tercera parte de todos los hogares en las cinco comunidades. Las personas que respondieron a la encuesta habían tenido individualmente un promedio de 5,5 experiencias traumáticas personales y habían presenciado un promedio de 7,3 episodios ajenos de carácter traumático. De las personas que participaron en la encuesta, 8,9\% satisfacían los criterios diagnósticos de SEP, 17,3\% los de ansiedad y 47,8\% los de depresión. El SEP mostró una asociación con haber sufrido heridas graves y con tener parientes que habían sido mutilados. Los análisis de regresión logística revelaron una asociación entre la presencia de estados de ansiedad y el haber sufrido agresión sexual, ser mujer, haber tenido amigos o parientes mutilados, haber sufrido heridas graves y tener de 6 a 12 hijos (frente a tener de 1 a 5). La depresión mostró una asociación con tener de 6 a 12 hijos. Los estados de ansiedad mostraron una prevalencia significativamente mayor entre los refugiados que se quedaron en México $(54,4 \%)$ que entre los que fueron repatriados $(17,3 \%)$. En cambio, no se observaron diferencias significativas entre los refugiados que permanecieron en México y los que fueron repatriados en cuanto a las tasas de prevalencia de SEP $(11,8 \%$ frente a $8,9 \%$, respectivamente) y de depresión (38,8\% frente a 47,8\%, respectivamente).

Conclusiones. Se observaron problemas psiquiátricos frecuentes en los mayas repatriados. La repatriación de refugiados entraña movilizar a una población que de por sí es vulnerable y que ha sido víctima de muchos traumas a un lugar cargado de recuerdos dolorosos y donde siguen imperando condiciones muy precarias. Es preciso, por ende, contemplar la necesidad de planificar servicios de salud mental para refugiados repatriados.

Palabras clave Refugiados, migración internacional, salud mental, trastornos por estrés postraumático, Guatemala. 